\title{
Yunanlıların Batı Anadolu'da Nüfus Çoğunluğunu Sağlama Gayretleri ve Yunan Hükümeti'nin Bir Genelgesi
}

\author{
Dr. Serdar SARISIR*
}

\section{ÖZET}

Yunanlılar, işgal ettikleri Anadolu topraklarında kalıcı olabilmek için, işgalin temel dayanaklarından biri olarak ileri sürdükleri Rum nüfusunun çoğunlukta olduğu düşüncesini -aslında böyle olmayışın verdiği kaygıyla- gerçekleştirmek adına, Batı Anadolu'ya Rum göçmenler getirip yerleştirmeyi planlamışlar ve bunu bir program dahilinde sistemli bir şekilde gerçekleştirmişlerdir. Gün geçtikçe ortaya çıkan yeni belgeler, Yunanlıların Rum göçmenlerin iskânı işini, Anadolu'daki emellerinin geleceği için hayati bir önem taşılı̆̆ı bilinciyle ve bu öneme nisbeten de sistemli bir şekilde gerçekleştirme çabası içinde olduklarını göstermektedir. Bu çalışmada; Yunanlıların, Batı Anadolu'da nüfus çoğunluğunu sağlamaya yönelik girişimlerini bir program dahilinde gerçekleştirdiklerini gösterir kanttlar sunan yeni bulgular üzerinde durarak değerlendirmeyi ve katkı sağlamayı amaçlamaktadır.

Anahtar Kelimeler: Batı Anadolu, Yunanlılar, İşgal, Rum Göçmenler, İskan, Genelge

The Greek Attempts to Form the Majority and The

$$
\text { Memorandum Drawn }
$$

\section{ABSTRACT}

The Greek government planned to settle the Greek immigrants in the Western Anatolia occupied by the Greek army so as to claim later that the Greeks formed the majority. This would help to keep a permenant occupation there. The Greek government put this aim into execution with a sistematic program. The new documents coming out from the Archives show that the Greeks paid a great attention to the settlement of Greeks in the Western Anatolia as far as the Greek aims in Anatolia were concerned. To realize this aim it was important that the Greeks had to form the majority in terms of population there. This study will focus primarily on the

\footnotetext{
• Niğde Üniversitesi Fen-Edebiyat Fakültesi Tarih Bölümü
} 
Greek attempts that would lead to hold the majority on the basis of the recently disclosed documents in the Turkish Archives, especially the Memorandum drawn by the Greek government and distributed to their occupying forces in Anatolia,. These documents will be used and evaluated in this frame.

Key Words: Western Anatolia, Greeks, Occupation, Greek immigrants, Settlement, Memorandum.

\section{GİRIŞ}

Yunanlılar, işgal ettikleri Anadolu topraklarında kalıcı olabilmek için, işgalin temel dayanaklarından biri olarak ileri sürdükleri Rum nüfusunun çoğunlukta olduğu düşüncesini -aslında böyle olmayışın verdiği kaygıylagerçekleştirmek adına, Batı Anadolu'ya Rum göçmenler getirip yerleştirmeyi planlamışlar ve bunu bir program dahilinde sistemli bir şekilde gerçekleştirmişlerdir. Anadolu'da yaşanan bu olgunun tarihi seyrine baktığımızda, Yunan emelleri ve isteklerinin genelde demografik bir temele dayandırılmaya çalışıldığı görülmektedir. Yunanlılar, Paris Konferansı'nda isteklerini Wilson Prensipleri'ne, özellikle de prensiplerin 12. maddesine "self determinasyon"- ilkesine dayandırma gayreti içinde olmuşlardır. Bu anlamdaki Yunan istekleri ekonomik ve hissî-tarihi delillere dayandırılmaya çalışılmış ise de, girişimlerinin temel çıkış noktası ve ana dayanakları daima milliyetler prensibi olmuştur'. Venizelos'un Batı Anadolu üzerindeki toprak isteklerinin resmi tutanaklara göre ilk gerekçesi de, Wilson'un 12. ilkesi ${ }^{2}$ olmuştur. Bu doğrultuda Batı Anadolu'da istenen yerler ise aşağı yukarı, Karadeniz'den Antalya Körfezi'ne, kuzeyde İzmit'in doğusundan, güneyde Antalya Körfezi'nin batısından geçmek üzere çizilecek bir çizginin batısında kalan tüm bölgeyi kapsamaktaydı. Yani Venizelos, “1.013.195 Rum'un yaşadığını" ileri sürdüğü Batı Anadolu'nun tümünü ${ }^{3}$ ve Anadolu'nun devamı ve buralarda yaşayan nüfusun çoğunlukla Rumlardan oluştuğunu iddia ettiği doğu Akdeniz adalarının tümünü de yine milliyetler prensibini dayanak göstererek, istemekteydi ${ }^{4}$. Yunanlıların girişimleri nihayet sonuç bulmuş ve İtilâf Devletleri Paris Barış Konferansı'nda, 10 Mayıs 1919 tarihinde İzmir'in Yunanlılar tarafından işgal edilmesini kararlaştırmışlardır. Söz konusu kararı da, 14 Mayıs 1919 tarihinde İstanbul Hükümeti'ne bildirmişlerdir ${ }^{5}$.

Böylece, Yunanlılar talep ettikleri topraklarda nüfus çoğunluğunu sağlamak için bir dizi planı işgalle birlikte uygulama fırsatını

' Yahya Akyüz, Türk Kurtuluş Savaşı ve Fransız Kamuoyu (1919-1922), Ankara 1975, s. 73 vd.; Salahi Ramadan Sonyel, Türk Kurtuluş Savaşı ve Dış Politika, C. I, Ankara 1995, s. $35 \mathrm{vd}$.

${ }^{2}$ A. Suat Bilge, Büyük Düss, Türk Yunan Siyasi ilişkileri, Ankara 2000, s. 44.

${ }^{3}$ Dimitri Kitsikis, Yunan Propagandast, (Çev. Hakkı Devrim), İstanbul 1974, s. 18; Türk Istiklâl Harbi II. Cilt Batı Cephesi 2nci Kısım, Ankara 1999, s. 3.

${ }^{4}$ Kitsikis, a. g.e., s. 20-21; Bilge, a. g.e., s. 41,45-46.

${ }^{5}$ İzzet Öztoprak, Türk ve Batl Kamuoyunda Milli Mücadele, Ankara 1989, s. 46. 
bulabilmişlerdir. Bu demografik planın halkalarından biri, Türklerin sürgün edilmesi, diğeri ise, sözde Türkler tarafından göç ettirilmiş Rumların geri getirilerek iskân edilmesidir. Biz daha çok çalışmamızda, Rum göçmenlerin iskânı işinin nasıl bir program dahilinde gerçekleştirildiğini, ilkini daha önce yayınladığımız iki genelge üzerinde durarak ortaya koymaya çalışacağız. İşgal altındaki Türk topraklarına baktığımızda, Yunanlıların planlarını gerçekleştirmek için hiç vakit kaybetmeden çalışmalara başlamış olduklarını görürüz. Zira, 15 Mayıs'tan itibaren Yunanlılar, Rum göçmenleri iskân etmeye başlamışlar ve sadece Batı Anadolu'da değil tüm işgal bölgelerinde Rum nüfusunu çoğaltma girişimlerini giderek artan bir şekilde devam ettirmişlerdir. Osmanlı Hükümeti, durumun ciddiyetinin farkında olmakla birlikte, söz konusu gelişmeler karşısında bazı tedbirler almaya çalışmı̧ ise de, bu konuda pek başarılı olamamış ve bölgede Rum nüfusunu artırmak amacıyla gerçekleştirilen, nüfus kaydırmalarının önü alınamamıştır ${ }^{6}$.

Yunanlıların bu anlamdaki çalışmaları ise, gelişi güzel bir şekilde yapılmamıştır. Yunan Hükümeti, İzmir'de Rum nüfusunun çoğunluğunu sağlamak üzere; Yunan ordusu tarafından işgal edilmiş şehir ve kasabalardan sürgün edilmiş binlerce Türk'ün yerine, Balkan Savaşları'ndan sonra kurulmus olan Osmanl1-Yunan Mübadele Komisyonu'nun kararı ve uygun görüşleri doğrultusunda, mübadele edilmiş ve Makedonya'daki Müslümanların mülklerine İskân ettirilmiş Rumlarla, Birinci Dünya Savaşı nedeniyle Osmanlı Ordusu'nda görev yapmamak için kaçmış Rumların, İzmir ve işgal bölgelerinde iskân ettirilmesi fikrini benimsemiş ve bu doğrultuda incelemelerde bulunması ve bölgede Yunan nüfusunun çoğunluk hâline getirilmesi için gerekenleri yapmak üzere, olağan üstü yetkilerle donattığ 1 İstiriyadis'i söz konusu amacına ulaşmak üzere, İzmir'e vali olarak atamış ve bu konuyla ilgili olarak da iki genelge hazırlayarak çalı̧̧malarını gerçekleştirme yoluna gitmiştir.

İstiryadis, İzmir ve hinterlandındaki Müslümanların sayısının tespit edilmesi, Rumların bölgede çoğunluk hâline getirilebilmesi için ne kadar Rum'un bölgeye yerleştirilmesinin gerekli olduğunu incelemek ve tespit etmek üzere; İzmir, Kuşadası, Çeşme ve Manisa Metropolitleri'nin de arasında yer aldığ 1 on iki kişilik, bir komisyon kurdurmuştur. Bu komisyon da, yaptığı araştırmalar sonunda, çoğunluğun Rumlara geçmesi için kaç bin Rum'un bölgeye göç ettirilmesi gerektiğini hesap ve ilâve ederek, hazırladıkları raporu İstiryadis'e sunmuştur. İstiryadis, söz konusu rapora, kendi görüşlerini de ilave ederek, Yunan Hükümeti'ne rapor hakkında gerekli sözlü bilgilendirmeyi yapmak üzere, Çeşme Metropoliti ile Çeşme Rum göçmenlerinin delegesi, Pandazidoi'yi Atina'ya göndermiştir.

${ }^{6}$ Serdar Sarısır, Demografik Oyun Sürgün (1919-1923), İstanbul 2006, s. 336 vd; Mütareke döneminde Anadolu'da Rum nüfusunu artırma çabaları için ayrıca Bkz. Aynı eser, s. $130 \mathrm{vd}$. 


\section{Yunan Hükümeti'nin Birinci Genelgesi}

Venizelos'un, Anadolu'daki emellerinin geleceği için hayati bir önem addettiği Rum göçmenlerin iskânı meselesini, Yunan Hükümeti de Venizelos'un fikirlerine katılmak suretiyle kesin olarak tayin ve tespit etmiş ve bu konuda kararını vererek kapsamlı bir genelge hazırlayarak uygulanmasına girişmiştir ${ }^{7}$. Yunanistan, işgal ettiği bölgelerdeki Rum nüfusunu arttırmak amacıyla, Birinci Dünya Savaşı'ndan önce ve savaş sırasında adalara göç etmiş Rumların, Yunan işgali altında bulunan bölgelere iskânlarını sağlamak için, Yunan İçişleri Bakanlığı aracılığıyla, işgal bölgelerindeki Yunan yetkililerine hitaben göndermiş olduğu genelgeye göre, Yunan Hükümeti kendisinin yardımına muhtaç olmayan, kendi kendine geçimini sağlayabilecek ekonomik yeterliliğe sahip bulunan Rumların, Aydın vilayeti ve Ayvalık havalisine iskânları amacıyla bölgeyi on mıntıkaya ayırmış ve yerleşecekleri yerlere giderken karaya çıkacakları iskeleleri de belirlemiştir.

Söz konusu genelgeye göre, göçmen Rumların karaya çıkacakları iskeleler ve iskân edilecek yerleşim yerleri aşağıdadır:

1- İzmir, Develiköy, Malfeci, Kitmidya, Akyon, Buca, Bornova, Kordolid, Hacılar, Cumaovası, Kaya, Torbalı, Kokluca, Pınarbaşı ve havalisindeki yerlere iskân edilecek Rumlar, İzmir İskelesi'nden karaya çıkacaklardır.

2- Ayvalık, Gömeç, Yayaköy, Kıranköy, Ayazma, Yeni Sarı Havra ve havalisine iskân edilecek Rumlar, Ayvalık İskelesi'nden karaya çıkacaklardır.

3- Yeniköy, Karlıdere, Ayayorgi Çiftliği, Klizman havalisine iskân edilecek Rumlar, İzmir İskelesi'nden karaya çıkacaklardır.

4- Urla, Güllüce, Manisa, Yukarı Demir Çelebi, Patrol, Gülbahçe havalisine iskân edilecek Rumlar, Urla İskelesi'nden karaya çıkacaklardır.

5- Menemen, Sereköy, Çile, Ulucak, Aliağa ve Arapdere havalisine iskân edilecek Rumlar, İzmir İskelesi'nden karaya çıkacaklardır.

6- Bergama, Soğancılar, Açanos, Çandarlı, İzmanlar, Rumköy, Makaronya, Kabakum, Kalişeköy, Sutraziler, Dikili ve havalisine iskân edilecek Rumlar, Dikili İskelesi'nden karaya çıkacaklardır.

7- Meli, Eğri Liman, Küçük Bahçe, Denizgiren, Salmaklı, Sazak, Halicik, Hasköy, Yeni Liman, Tepeboz, Ahırlı, Şeybe, Manastır, Anbarseki, Megali Molovami, Teke Mikro Molivami ve havalisine iskân edilecek Rumlar, bu köylerin civarındaki körfezlerden karaya çıkacaklardır.

${ }^{7}$ Mithat Sertoğlu, "Anadolu'muz Hakkında Yunanlıların Düşünce ve Emelleri”, Belgelerle Türk Tarihi Dergisi, S. 19, Nisan 1969, s. 19. 
8- Aşağı Pabaya, Aya Paraşköy, Rişdere, Kirmanlı, Litra, Ovacık, Ağıryaba ve havalisine iskân edilecek Rumlar, Çeşme İskelesi'nden karaya çıkacaklardır.

9- Eski Foça, Kiliş Beğli, Çomaklı, Bari, Bağarası ve havalisine iskân edilecek Rumlar Eski Foca İskelesi'nden karaya çıkacaklardır.

10- Seferihisar, Ödemiş, Tire, Nif, Manisa, Kasaba ${ }^{8}$ da Rum göçmenlerin yerleşebilecekleri bölgelerin arasındadır.

Yunan Hükümeti, bu genelge aracılı̆̆ıla iskânın nerelerde gerçekleştirileceğini ortaya koymakla, Rum göçmenlerin bir disiplin dahilinde hareket etmelerini sağlamayı amaçlamıştır. Böylece, gelişi güzel gerçekleşecek bir göçte oluşabilecek kargaşa ortamının önüne geçilmiş olmakla birlikte, nüfus çoğunluğunun sağlanması işi de, tesadüfe bırakılmamış olacaktır. Zira, daha önce İstiriyadis'in kurduğu komisyon tarafından organize bir şekilde yapılan saha araştırmaları neticesinde, mevcut Türk ve Rum nüfusunun miktarı ve Rumların nüfus çoğunluğunu sağlayabilmesi için gerekli olan göçmen miktarı, tespit edilmiş olduğundan; bu genelgede yer alan yerleșim yerlerinin tesadüfi olarak değil de, söz konusu saha araştırmalarının sonuçlarına göre, belirlenen yerler olduğu anlaşılmaktadır. Rum göçmenlerin sevkiyatı deniz yoluyla gerçekleştirileceği için, karaya çıkacakları yerlerde dengeli bir dağılımla, mevcut limanlardan maksimum yaralanmayı hedeflemiş oldukları anlaşılmaktadır.

Böylece Yunanlılar, kısa bir zaman içinde söz konusu bölgelerde ezici bir nüfus çoğunluğu sağlamak üzere, Balkan Savaşı'ndan sonra mübadele edilmiş Rumlarla, askerlikten kaçmış Rumları ve fazladan da; Yunan ana karasından ve Adalardan bir çok Yunanlıyı, kendilerine arazi ve çiftlik verileceği vaadiyle, Anadolu'ya naklettirip işgal altındaki arazide namus ve hayatlarını kurtarmak üzere varını yoğunu ve yurtlarını terk etmek zorunda kalmış insanların yerine yerleştirmeyi hedeflemişlerdir. Bu nakil işi bittikten sonra Venizelos'un, İzmir ve civarının "bir Yunan șehri" olduğunu ve büyük çoğunluğunun Yunanlılardan oluştuğunu ileri sürüp, durumun resmi olarak tespiti için yeni bir nüfus sayımının yapılması konusunda, İtilâf Devletleri'ne baş vurabileceği ve bunda ısrar edeceği; istek ve arzusunun da gerçekleşeceği ${ }^{9}$ güçlü bir olasılıktır.

Burada dikkat çeken ilginç bir husus da, Rum göçmenlerin profilleridir. Her ne kadar genelgede, kendi başlarına geçimlerini sağlayabilenler ibaresi bulunmakta ise de, Arazi ve çiftlik verileceği vaadiyle yerini yurdunu bırakan Rumların, nasıl bir iktisadi ve toplumsal bir tabakanın mensubu olduklarını tahmin etmek güç olmasa gerektir. Atina'da yaşayan hali vakti yerinde bir Yunanlının ya da Giritli bir armatörün ya da hayatından memnun Sakızlı bir balıkçının bu vaatlere istinaden kalkıp Anadolu'ya gelmesini

\footnotetext{
${ }^{8}$ Sarısır, gös. yer.

${ }^{9}$ Sertoğlu, a. g. m., s. 20.
} 
ummanın zayıf bir olasılık olması; gelenlerin daha ziyade, Yunan toplumsal hayatında tutunamamış, suça meyyal maceraperestler olduğu düşüncesini güçlendirse gerektir. Hal böyle olunca da, Rum göçmenlerin iskân edilmek istedikleri yerleşim yerlerindeki davranışlarını tahmin etmek güç olmamalıdir.

\section{Yunan Hükümeti'nin İkinci Genelgesi}

Söz konusu genelgeyi tamamlayan tespit ettiğimiz ikinci genelge ise, daha çok ilk genelgeyle belirlenmiş iskân mahallerinde yerleştirmenin gerçekleşmesi esnasında, yapılması gereken işlemleri ihtiva etmektedir. Yunan Hükümeti'nce, İşgal Kumandanlı̆̆ına, İnzibat Kuvvetleri Müdüriyeti'ne ve tüm işgal mıntıkalarındaki Yunan Fevkalade Komiserliği temsilcilerine tebliğ olunan; Rum göçmenlerin dönüşleri ve iskânları hakkında uyulması gereken kuralları içine alan, söz konusu genelgeye göre;

Yunan Hükümeti, Aydın vilayetinin tümüyle, Ayvalık ve Yunda (Ali Bey Adası) mıntıkasına Rum göçmenlerin geriye dönüşüne daha önce müsaade etmiş olmasına rağmen; (Bkz. birinci genelge 2. madde), bazı özel nedenleri olduğu gerekçesiyle, ikinci bir beyana kadar Çeşme, Alaçatı ve Yeni Foça kasabalarıyla Eski Foça'nın Germeköy adlı karyesine, Rum göçmenlerin iskânına yasaklama getirmiş ve Yunan yetkililerinden de, yukarıda adı geçen; iskâna kapalı kasabalara, hiç bir kimsenin geriye dönüşüne ve iskânına müsaade etmemelerini, gizli bir şekilde yerleşmeye kalkışanların da hemen tutuklanarak geldikleri yerlere derhal geri gönderilmelerini istemiştir.

Genelgeye göre; geri dönüş ve yerleşmenin serbest olduğu mıntıkalara göç eden Rum göçmenler; geldikleri yerin inzibat kuvvetlerinden ve idari mülkiyesinden verilen onaylanmış özel izin belgelerine sahip olmadıkça, iskânlarına müsaade olunmayacaktır.

Geri dönen Rum göçmenlerin pasaport ve izin belgeleri, gelişleri esnasında sıkı bir kontrole tabî tutulacak ve ayrılıș izin belgesine sahip olmayanlar hemen geldikleri yere iade edileceklerdir. Geçen beş sene zarfında Rumlara ait hanelerin bir çoğu yıkılmış; bir çoğu kullanılamaz bir hale gelmiş ve bir kısmı da, Osmanlı Hükümeti tarafından yerli veya Müslüman göçmenlere bedelsiz veya icar suretiyle verilmiş olması nedeniyle; bir taraftan sakinlere kifayet edebilmesi ve diğer taraftan da geriye dönen Rum göçmenlerle; kendilerinin hanelerinde bulunan İslâmlar arasında çekişme, kavga vb olayların ortaya çıkmasına meydan verilmemesi için aşağıdaki tedbirleri başvurmak gerekmektedir.

Şöyle ki:

1- Geriye dönen Rumların; kendi başlarına, kendi hanelerine yerleşmeleri yasaklanacak ve verilen emirlere karşı gelenler hemen tutuklanarak, bölgeden uzaklaştırılacaklardır. Rum göçmenlerin iskânı Fevkalade Komiserlikçe her mahalde tayin edilecek memurlar ile ayrıca 
teşkil edilecek ve bu memurların verecekleri talimata bağlı hareket etmekle mükellef birinci ve ikinci derece komisyonlar vasıtasıyla icra edilecektir. Bundan dolayı, Rum göçmenlerin geri dönüşleri başlamazdan önce; her bir yerleşim yerinde bulunan, oturulan türden hanelerin miktar ve sahipleri layıkıyla ve hızlı bir şekilde iş bu komisyonlar marifetiyle tahkik edilecek ve her hanede tercihen sahibi iskân ettirileceklerdir.

Haneleri yıkılmış, harap olmuş veya Müslümanlar tarafından yerleşik bulunan Rum göçmenler; komisyonlar marifetiyle; boş hanelere ve eğer bu boş haneler mevcut değilse; kendi hanelerine iskânlarına değin; fazla yeri olan hanelere, geçici olarak yerleştirileceklerdir.

Rum göçmenlerin iskânından sorumlu komisyonlar,

1- İskan edilen her bir ailenin sahip olduğu ferd sayısını;

2- Bu fertlerin isim ve şöhreti; eşi, sanatı, iktisadi ve sıhhi vb. durumlarını kayda mahsus bir defter tutacaklar ve bu surette tanzim edilen defterleri, Göçmen İskân Memurlukları'na tevdî edeceklerdir. Göçmen İskân Memurları da komisyonlar tarafından verilen iş bu bilgiler doğrultusunda, genel bir cetvel düzenleyerek, Fevkalade Komiserliğin Göçmen İskânı Şubesi'ne göndereceklerdir.

Geri dönen Rum göçmenlerin, arazi ve emlaki kendiliğinden veya Osmanlı Hükümeti'nin izniyle bedelsiz veya istihbar suretiyle yerli veya göçmen İslâmlar tarafından işgal edilmiş olması ihtimaline karşın, geri dönen göçmenler, bu emlake yerleşmek istedikleri zaman genel asayişi ihlal edebilecek arzu edilmeyen durumların zuhuru ihtimal dahilinde bulunması nedeniyle, hiçbir kimsenin kendi başına, kendi emlakına yerleşmesine müsaade edilmeyecek ve bu doğrultudaki emirlere muhalefet edenler hemen tutuklanacaklardır.

Geriye dönen Rum göçmenlerin, kendilerine ait terkedilmiş emlaklarına yerleştirilmesi ve söz konusu emlaklarının kendilerine iadesi, yukarıda bahsedilen komisyonların sorumlulukları altında icra edilecektir. Ancak, daha evvel, olduğu,

1- O mülkte iskân ettirilecek kimsenin hakikaten o mülkün sahibi

2- Söz konusu mülkün metruk olup; göçmen veya yerli bir Türk'ün işgali altında bulunmadığının layıkıyla tetkiki gereklidir. Geriye dönen göçmenlere ait olup da, berat veya göçmen Türklerin elinde bulunan emlake gelince: Aşağıda ifade edilen yapılması gerekli uygulamaların takip edilmesi gerekmektedir.

1- Eğer bu türden emlakı halihazırda işgalleri altında tutanlar, buralara kendi başlarına yerleşmiş iseler, hemen zabıta marifetiyle söz konusu emlaktan çıkartılarak, ciddi bir tetkik neticesinde emlakın sahibi olduklarını ispat edebilenler oralara yerleştirileceklerdir. 
2- Eğer söz konusu emlakı işgalleri altında tutanlar, oralara Yunan Hükümeti'nce yerleştirilmiş iseler, bu yerleştirilmenin o mıntıkanın Yunan kuvvetlerince işgalinden önce sakıncalı olup olmadığı konusunu dikkate alacaklardır.

Eğer yerli veya göçmen Türkler bu emlaka; Yunan işgalinden sonra yerleştirilmiş iseler, hemen ve icabında zabıta marifetiyle söz konusu emlak tahliye ve sahiplerine iade edilecektir. Şu karar var ki, bu taktirde verilecek iskân izni ve emlakın iadesi komisyonlar tarafından değil; özel Göçmen İskân Memuru tarafından gerçekleştirilecektir. Yunan Hükümeti'nin emir ve özel izni olmadıkça, yukarıda tespit edilen hallerin dışında, geriye dönen göçmenlerin, hiç birinin iskân ettirilmesi uygun değildir. İskan meselesinin başarılı bir şekilde tamamlanabilmesi için görevlilerin; söz konusu genelge hükümlerini dikkatle uygulaması gerekmektedir. Göçmenlerin iskânına yönelik olarak mahalli temsilciler tarafından verilecek her bir emrin, itirazsız icrasını ve genel asayişin korunmasını İnzibat Müdürlüğü sağlayacak ve gerekli olduğunda; iş bu talimatname hükümlerinin tatbiki için İnzibat kuvvetlerine gerekli yardımda bulunulması da, İşgal Kuvvetleri Kumandanlığı'nın sorumluluğu altında olacaktır ${ }^{10}$.

Söz konusu genelgenin varlığı, uluslararası hukuk nezdinde tartışmalı olması gerekli iken; genelgenin tam anlamıla uygulanmasını da beklemek zor olsa gerektir. Yunanlılar, Türkler tarafından göç ettirildiğini iddia ettikleri Rumları geriye getirerek iskân ettiklerini ifade etmelerine rağmen; onların Türkler tarafından göç ettirildiği söylenen Rum nüfusu kadar, Rumu geri iskân ettiklerini kim bilebilir ya da denetleyebilir ki, Osmanlı Devleti'nin bunu yapması mümkün gözükmemekle birlikte en iyimser yaklaşımla, bu durum batılı devletlerin dikkate alması gereken bir nokta olarak düşünülebilir. Ancak, bu da mümkün gözükmemektedir. Çünkü uluslararası hukuk batılı devletlerin kendi amaçlarına hizmet ettikleri oranda işlerlik kazanmış, aksi durumda sanki yokmuş gibi davranılmıştır. Zira Yunanlılara bu firsatları sunanlar da onlar değilmidirler.

Osmanlı Hükümeti, bölgede yaşanan tüm olup biteni takip etmekle birlikte, Yunanlı yetkililer nezdindeki girişimleri açıklama talebinden ve konunun çözümünü batılı devletlere havale etmekten öteye gitmemiştir. Örneğin, Osmanlı Hükümeti; İzzet Bey aracılı̆̆ıyla, Vilayet-i Umur-u Hukuk Müdürü Dimitraki Efendi ve Fevkalade Komiser İstiriyadis nezdinde bir girişimde bulunmuş ve bölgede yaşanılanlar hakkında bir açıklama talep etmiştir. Ancak, verilen cevap da, Rum göçmenlerin iskânı işini söz konusu genelge hükümlerine göre ve Türklerin haklarının gözetilerek gerçekleştirildiği ifade edilmiştir. Ancak, söz konusu genelge hükümlerinin hiç birisine uyulmadığı, Sakız Adası vb ada ve yerlerden getirilen Rumların mevcut boş hanelerin dişında, meskenlerinden ve arazilerinden zor ve tehdit

10 Başbakanlık Cumhuriyet Arşivi, 272.11/15.55.12, Aydın Valiliği'nden Dahiliye Nezareti'ne gönderilen 13 Ocak 1920 tarihli yazı, s. 2-3. (Bundan böyle B.C.A. şeklinde gösterilecektir). 
ile ve Yunan işgal kuvvetlerinin tazyikleri sonucu çıkarılan, Türklerin yerlerine de iskân edildikleri görülmüştür ${ }^{11}$.

Genelge hükümlerine bakıldığında ve Batı Anadolu'da fiiliyatta yaşananlar göz önünde bulundurulduğunda, gerçekten de, Yunanlıların Rum göçmenlerin iskânı konusunda kendi hazırladıkları genelgeye bile uymadıkları görülmüştür. Örneğin, Ayvalık bölgesi genelgeye göre yasak bölge olmasına rağmen, çok geçmeden buraya Rum göçmenler getirilip iskân edilmiştir. İzmir'in işgalinden Ocak 1921'e kadar, Ayvalık'a 22.000 Rum göçmenin iskân edilmiş olduğu Yunan kaynaklarının ifadesidir ${ }^{12}$. Çeşme'de, genelgenin aksine, Rum göçmenlerin iskânının gerçekleştirildiği yerlerdendir.

Yine genelgede, Rum göçmenlerin iskânı gerçekleştirilirken yerli veya göçmen Türklerle, Rumlar arasında bir sorunun yaşanmaması ve genel asayişin teminine dikkat edilmesinin gerekliliği hususunda yetkililerin dikkatli olmaları gerektiği üzerinde durulmakta ise de, bizzat kendisi komisyon üyesi olan ve vaktiyle mübadeleye tabi olarak Anadolu'yu terk eden, fakat işgali müteakip beraberindekilerle birlikte Yunanistan'dan geri dönmüş olan Çeşme Metropolidi Kalonikos Efendi'nin; Alaçatı'daki kiliselerin resmi açılışını yapmak için bir kiliseden diğerine giderken geçtiği yerlerde, beraberindeki Rum göçmenlerin meskun Türklerin dükkanlarındaki malları talan ettikleri, Giritli Cemal Efendi'nin babasını çok kötü bir şekilde darp ettikleri ve meskun Türklerin Çeşme'den göçünü önlemek için Çeşme'de bulunan Vilayet-i Muhacirin İdaresi Fen ve Ziraat memurlarından Hüseyin ve Kenan efendileri bilinmeyen nedenlerden dolayı zorla kaza dışına çıkardıkları, göçmen Rumlar tarafından daima Türklük ve islâmiyete karşı hakaretlerde bulunulduğu, Çeşme Kaymakamlığı'ndan alınan haberlerden anlaşılmaktadır.

Genelge gereği yerel memurların, gerek nüfus tespit işlerini ve gerekse Türklerin meskenlerini boşaltmaları konusundaki çalışmalarını ise, daha bir dikkatli yapmış oldukları görülmektedir. Örneğin, Çeşme'de Yunan İskân Komisyonu Başkanı Markaki tarafından, yöre halkı kiliseye toplatılarak, hane, dükkan, mağaza ve arazilerini 15 gün zarfında tahliye etmeleri ihtarında bulunmuş ve muhtardan Çeşme'deki Müslüman muhacirlerin nüfusu ve memleketlerini yazan bir defter istemiştir ${ }^{13}$.

Osmanlı Devleti'nin tüm girişimlerine rağmen, Yunanlıların Batı Anadolu'da işgal ettikleri bölgelerde Rum nüfusu arttırma çabaları devam etmekte, Türkler meskenlerinden ve arazilerinden zorla çıkarılarak yerlerine Rum göçmenler yerleştirilmektedir. Çaresiz Türkler bu baskı karşısında

"B.C.A., 272.11/15.55.12, Aydın Valiliği'nden Dahiliye Nezareti'ne gönderilen 13 Ocak 1920 tarihli yazı, s. 1 . $15-17$

${ }^{12}$ Bilal Şimşir, Ingiliz Belgeleri İle Sakarya'dan İzmir'e (1921-1922), İstanbul 1972, s.

${ }^{\text {i3 } B . C . A ., ~ 272.11 / 15.56 .5, ~ A y d ı n ~ V a l i l i g ̆ i ' n d e n ~ D a h i l i y e ~ N e z a r e t i ' n e ~ g o ̈ n d e r i l e n ~} 25$ Ocak 1920 tarihli yazı, 
yurdunu yuvasını terk etmek zorunda kalarak oraya buraya dağılmaktadırlar. Yine Çeşme'den vereceğimiz bir örnekte görüldüğü üzere, hanelerinden çıkarılan insanlar Çeşme'yi terk etmenin yollarını ararken, baskılardan kurtulmak amacıyla Çeşme'den bir an evvel kaçmak için 300 kişi taşıyabilecek bir gemiye 1100 kişi binmek suretiyle kazadan ayrılmaya çalışmışlardır. Herhangi bir sorunla karşı karşıya kalmamaları için gemiyi inceleme girişiminde bulunan Liman Reisi İhsan Bey'in divan-1 harbe verileceği tehdidiyle bu teşebbüsü engellenmiştir.

Ancak, bu türden genelge dışı uygulamalarda bulunanların yine genelge gereğince tutuklanarak geldikleri yerlere geriye gönderilmeleri icap ederken, hiçbir göçmen Rum'un tutuklanarak geldiği yere geriye gönderilmiş olduğuna dair -konuyla ilgili biri olan tarafımızdan- Türk arşivlerinde hiçbir bir kayda rastlanılmamıştır ${ }^{14}$.

\section{SONUÇ}

Yunanlıların, Batı Anadolu'da Rum nüfus çoğunluğunu sağlama gayretlerini resmi bir prosedür dahilinde gerçekleştirdiklerini gösterir kanıtlar olarak -söz konusu iki genelge- değerlendirilebilir. Söz konusu süreçte, bu iki genelge; Batı Anadolu'daki Yunan amaçlarının gerçekleşmesinde üstlendikleri öneme binaen, gerçekleştirilmek istenen demografik planın belki de en önemli halkalarını oluşturmuşlardır. Batı Anadolu'da yaşanan süreç de bunu doğrular niteliktedir. Rum göçmenlerin iskânı konusunda araştırmalarda bulunması ve bölgede Yunan nüfusunun çoğunluk hâline getirilmesi için gerekenleri yapmak üzere, özel yetkilerle donatılan İstiryadis'in, İzmir Valisi olarak görevlendirilmesi, Yunan Hükümeti'nin bu anlamdaki ilk somut adımı olmuştur. Takip eden süreçte İstiryadis, İzmir hinterlandındaki Müslümanların sayısının tespit edilmesi, Rumların bölgede çoğunluk hâline getirilebilmesi için ne kadar Rum'un bölgeye yerleştirilmesinin gerekli olduğunu incelemek ve tespit etmek üzere; İzmir, Kuşadası, Çeşme, Manisa Metropolitleri'nin de arasında yer aldığı on iki kişilik, bir komisyon kurdurmuştur. Bu komisyonun çalışmaları neticesinde, göçmen Rumların karaya çıkacakları iskeleler ve iskân edilecekleri yerleşim yerleri on bölge olarak tespit edilmiştir. Yunan Hükümeti'nin, bir sonraki adımı ise, İşgal Kumandanlığına, İnzibat Kuvvetleri Müdüriyeti'ne ve tüm işgal mıntıkalarındaki Yunan Fevkalade Komiserliği temsilcilerine tebliğ olunan; Rum göçmenlerin dönüşleri ve iskânları hakkında uyulması gereken kuralları içine alan, söz konusu genelgeyi çıkarmak olmuştur. Bu genelge gereği Rum göçmenlerin iskânından sorumlu bulunan komisyonlar vasıtasıyla, iskân edilen her bir ailenin sahip olduğu ferd sayısı; bu fertlerin isim ve şöhreti; eşi, sanatı, iktisadi ve sıhhi vb. durumları kaydedilerek tanzim edilen defterler, Göçmen İskân Memurlukları'na gönderilmiş, Göçmen İskân Memurları da komisyonlar tarafından verilen iş bu bilgiler doğrultusunda, genel bir cetvel

${ }^{14}$ B.C.A., 272.11/15.56.5, Aydın Valiliği'nden Dahiliye Nezareti'ne gönderilen 11 Şubat 1920 tarihli yazı. 
düzenleyerek, Fevkalade Komiserliğin Göçmen İskân Şubesi'ne göndermişlerdir. Tüm bu gelişmelerin sonucunda; Yunanlıların Batı Anadolu'da nüfus çoğunluğunu sağlamak amacıyla işgallerle birlikte hayata geçirdikleri demografik bir projeyi adım adım ve resmi bir prosedür dahilinde -yukarıda kısaca ifade edildiği üzere- gerçekleştirdikleri görülmüştür.

\section{KAYNAKÇA}

\section{Başbakanlık Cumhuriyet Arşivi Belgeleri}

B.C.A., 272.11/15.55.12, Aydın Valiliği'nden Dahiliye Nezareti'ne gönderilen 13 Ocak 1920 tarihli yazı ve eki: Yunanistan'a göç eden ve geri dönen Rum göçmenlerin geri dönüşleri ve iskânları hakkında uyulması gereken kuralları içeren Yunan Hükümeti'nin genelgesi.

B.C.A., 272.11/15.56.5, Aydın Valiliği'nden Dahiliye Nezareti'ne gönderilen 25 Ocak 1920 tarihli yazı.

B.C.A., 272.11/15.56.5, Aydın Valiliği'nden Dahiliye Nezareti'ne gönderilen 11 Şubat 1920 tarihli yazı.

\section{Kitap ve Makaleler}

A. Suat Bilge, Büyük Düss, Türk Yunan Siyasi ilişkileri, 21. Yüzyıl Yayınları, Ankara 2000.

Dimitri Kitsikis, Yunan Propagandası, (Çev. Hakkı Devrim), Kaynak Kitapları, İstanbul 1974.

İzzet Öztoprak, Türk ve Batı Kamuoyunda Milli Mücadele, Türk Tarih Kurumu Yayınları, Ankara 1989.

Mithat Sertoğlu, "Anadolu'muz Hakkında Yunanlıların Düşünce ve Emelleri”, Belgelerle Türk Tarihi Dergisi, S. 19, Nisan 1969, ss. 14-22.

N. Bilâl Şimşir, İngiliz Belgeleri İle Sakarya'dan İzmir'e (1921-1922), Milliyet Yayınları,Istanbul 1972.

Salahi Ramadan Sonyel, Türk Kurtuluş Savaşı ve Dış Politika, C. I, Türk Tarih Kurumu Yayınları, Ankara 1995.

Serdar Sarısır, Demografik Oyun Sürgün (1919-1923), IQ Kültür Sanat Yayıncılık, İstanbul 2006.

Türk Istiklal Harbi II. Cilt Batı Cephesi 2nci Kısım, Genelkurmay Yayınevi, Ankara 1999.

Yahya Akyüz, Türk Kurtuluş Savaşı ve Fransız Kamuoyu (1919-1922), Ankara 1975, Türk Tarih Kurumu Yayınları. 


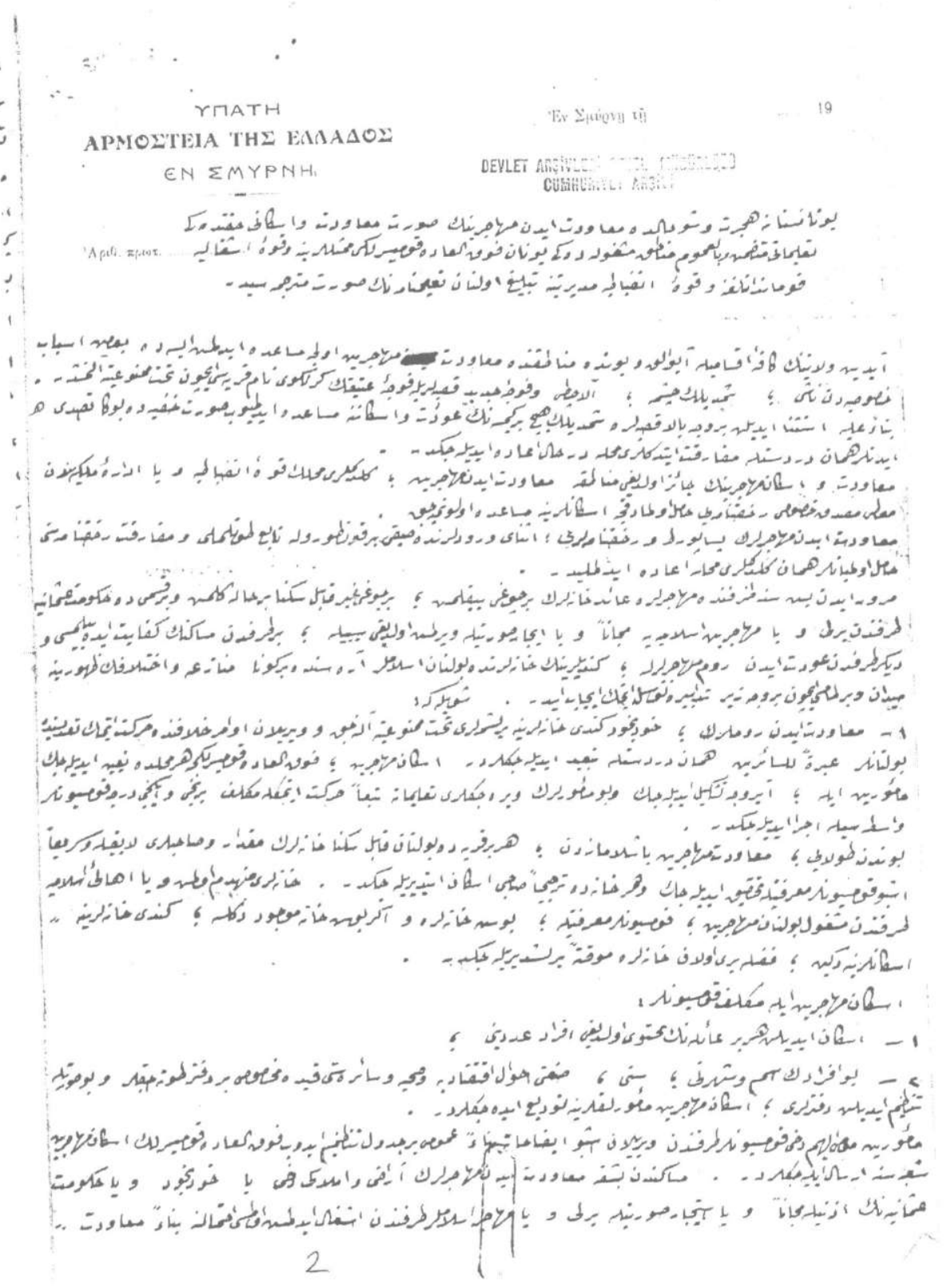

lik Cumhuriyet Arşivi, 272.11/15.55.12, s. 2; Rum göçmelerin iskânına dair genelgenin Yunanca'dan tercüme sureti 


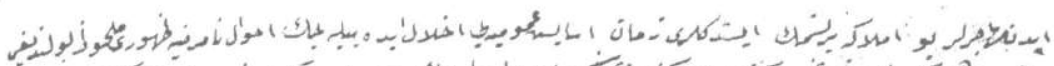

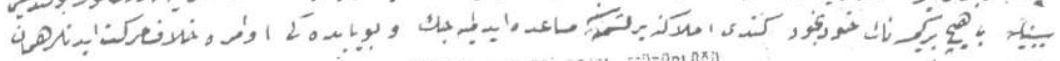

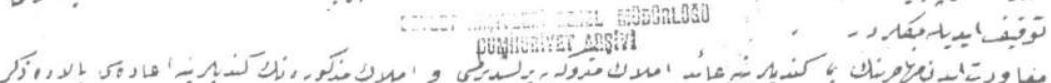

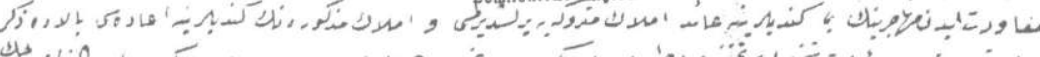

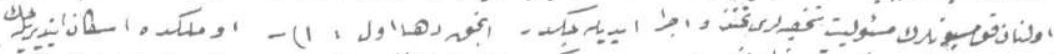

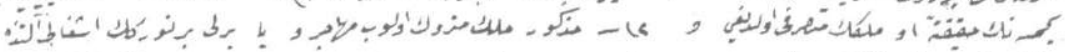

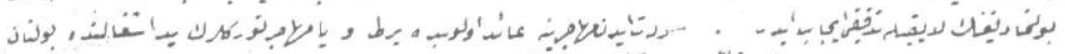

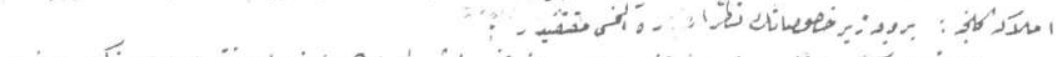

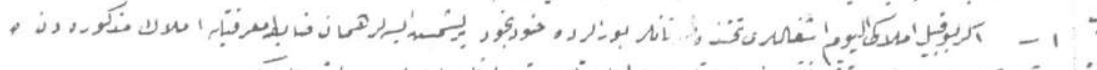

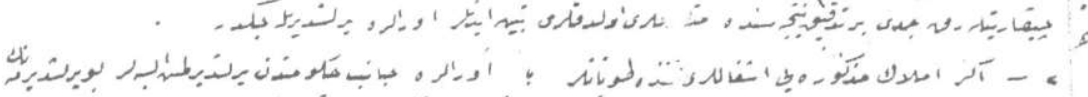

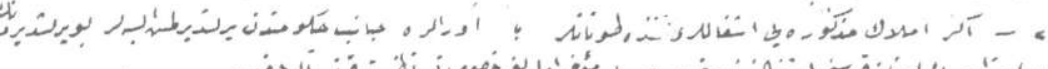

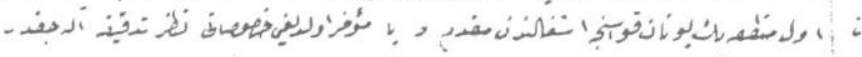

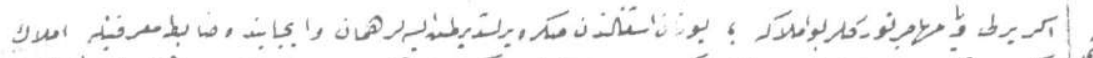

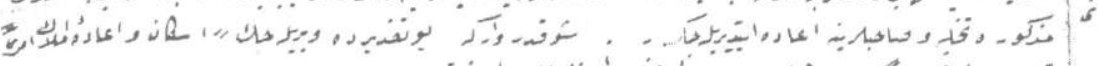

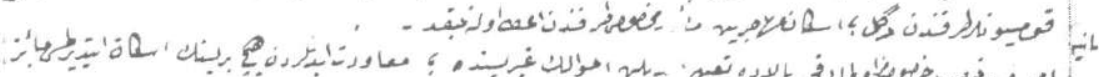

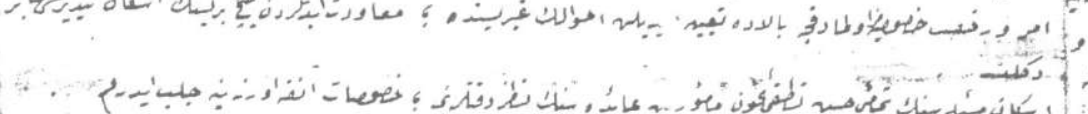

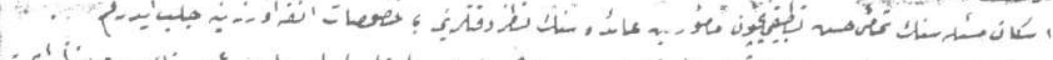

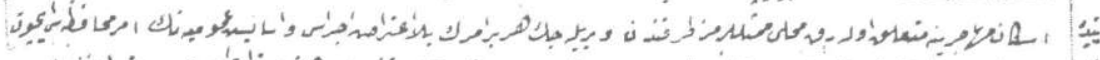

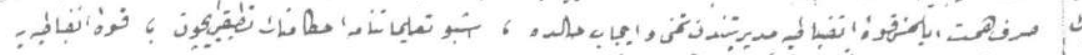

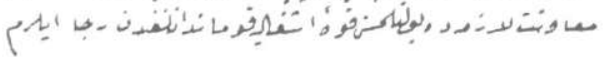

